\title{
FUNDAÇÃO JOAQUIM DOS SANTOS (TORREDEITA) DA ORIGEM À ACTUALIDADE*
}

\author{
Maria do Carmo Simões ${ }^{* *}$
}

\begin{abstract}
A fundação Joaquim dos Santos é uma Instituição Privada de Solidariedade Social, situada em Torredeita, numa das mais importantes e prósperas freguesias do concelho de Viseu. Foi fundada em 1967 por incumbência do Sr. Joaquim dos Santos. Funcionando como agente de desenvolvimento, cedo criou mecanismos e infra-estruturas de apoio ao desenvolvimento local e regional. Beneficiando os mais carenciados, desenvolve no aspecto social diversas valências, satisfazendo uma ampla e diversa população através da Creche, Jardim de Infância, Actividades de Tempos Livres, Lar de Idosos e do Apoio Domiciliário. Estando envolvida numa vasta cultura, desenvolve actividades culturais através de protocolos estabelecidos com o Rancho Folclórico de Torredeita e o seu Ecomuseu, sendo também dinamizadora e hospedeira da Cooperativa de Artesanato da Renda de Bilros e Trajes Regionais, "O Enleio". No aspecto educativo é promotora da Escola Profissional de Torredeita.
\end{abstract}

\section{INTRODUÇÃO}

Esta Fundação é uma Instituição Privada de Solidariedade Social, da qual fazem parte diversas valências; é promotora da Escola Profissional de Torredeita e tem acordos de cooperação com o Rancho Folclórico de Torredeita.

\footnotetext{
${ }^{*}$ Licenciada em Gestão e Desenvolvimento Social pelo Pólo de Viseu do Centro Regional das Beiras da Universidade Católica Portuguesa.
} 
A razão da escolha desta Fundação, para elaborar este trabalho, prende-se com o facto de ela ter desempenhado um papel preponderante e decisivo para - desenvolvimento da freguesia de Torredeita, quer a nível de infra-estruturas, quer a nível social e cultural.

Neste sentido, o trabalho está estruturado em seis pontos, uns mais extensos do que outros, dada a importância e a informação constante em cada área/aspecto a desenvolver.

No primeiro ponto, é feita uma abordagem à freguesia de Torredeita, à sua localização e ao papel desempenhado pela Fundação na freguesia.

O ponto seguinte é constituído pela génese da obra social e cultural, onde se faz uma pequena resenha histórica da origem desta Instituição e se focam os seguintes aspectos: quem foi Joaquim dos Santos; o papel do fundador; abordagem ao conceito de Instituição Privada de Solidariedade Social e a Apresentação da Instituição inserida nas várias vertentes.

No terceiro ponto, é tratado o aspecto cultural desta Fundação, que é concretizado pelo Rancho Folclórico de Torredeita com o seu Ecomuseu, pelo Lagar de Azeite da Cepeda, que é uma "peça" deste Ecomuseu, e pela Cooperativa de Artesanato "O Enleio", que se projecta na cultura do Rancho de Torredeita e do seu Ecomuseu.

O quarto ponto aborda a vertente social da Instituição com as valências: Creche e Jardim de Infância; Actividades de Tempos Livres e Lar com Apoio Domiciliário.

O quinto ponto incidirá no aspecto educativo e na relação sociocultural, com a Escola Profissional de Torredeita. Faz-se referência à identificação da Escola, aos cursos e níveis de formação prestados, bem como a outros aspectos relevantes para um melhor conhecimento desta Escola Profissional.

Para finalizar, o sexto e último ponto perspectiva um projecto futuro, um comboio histórico e turístico para a freguesia de Torredeita.

\section{BREVE HISTORIAL DA FREGUESIA DE TORREDEITA}

\subsection{Localização geográfica, evolução toponímia e actividades}

Quanto à localização geográfica, Torredeita é uma das importantes e prósperas freguesias do concelho de Viseu, cuja sede é a bela e sempre rejuvenescida capital da Beira Alta. "Torredeita está situada a $10 \mathrm{Km}$ de Viseu, com uma área de $15,72 \mathrm{Km}^{2}$, limitada a norte pela freguesia de Couto de Baixo, a sul pelas freguesias de São Cipriano e Farminhão e a poente pelo concelho de Vouzela"l, percurso que hoje se pode fazer através de uma rodovia (EN337), excelentemente pavimentada e bem sinalizada ${ }^{2}$. 
Constituem a freguesia as seguintes povoações: Torredeita, Routar, Vila Chã do Monte, Magarelas, Escouras, Casal, Vilas Covas, Novais, Várzea e Carqueijal.

Esta freguesia tem aprazíveis lugares dignos de uma visita; é típica a capela da Nossa Senhora do Ribeiro, erguida em 1620, em forma de navio. Existem também outros monumentos não menos belos, como a Igreja matriz de Nossa Senhora de Assunção, a capela de Nossa Senhora do Livramento, de Santo Estevão, para além de sepulturas talhadas na rocha, em Magarelas, e do Largar de Azeite da Cepeda, excelente cartaz etnográfico.

"Por volta de 1280 surge a Instituição da Paróquia de Santa Maria da Torre, aparecendo nas inquirições de D. Afonso III"3; é chamado o lugar e sede por Torre e não por Torredeita, dando-se assim início à evolução toponímica.

É possível que o topónimo Torre d'Eita seja anterior ao século XIII; Torredeita aparece muito recentemente por aglutinação das palavras TORRE, lugar e sede paroquial, e EITA, cuja origem tentaremos identificar, não havendo nada registado que nos dê certezas absolutas.

a) Assim, Torre designaria o lugar da Igreja e o topónimo devia designar o que hoje é a povoação de Torredeita, situada a nordeste desta Igreja. Quanto à palavra Eita, deriva do facto de, nessa época (séc. XI - XII), "terem existido nessa região dois senhores apelidados EITA, que tinham as suas maiores heranças sediadas na actual freguesia de Mosteiro de Fráguas, a cerca de $11 \mathrm{Km}$ a sul de Torredeita e que, um deles - um DOMNOEITA -, pai, poderá ter sido herdeiro desta parcela da "Vila" da Torre , o que vem originar, assim, o topónimo de TORRE D'EITA"4 Agora tudo se explicará melhor: TORRE, nome de "Villa" e EITA nome do melhor herdeiro, dono da terra. Outro facto que vem reafirmar esta hipótese é "o senhor DOMNOEITA ter tido dois filhos apelidados de EITAZ e que, por morte prematura do filho varão, a filha $\mathrm{D}^{\text {na }}$ GODOEITAZ ter herdado esta parcela, levando a crer, ... que o topónimo se deve a seu pai ...".

b) Outra hipótese é que "o nome de Torredeita deriva que ao lado da povoação da Torre, corre um pequeno ribeiro chamado Eita e assim foi explicada a etimologia de Torredeita (Torre d'Eita)"6. Este rio Eita passa no Arrabalde no lugar da Cepeda, onde antigamente fazia mover o moinho do Lagar de Azeite. Hoje em dia este rio ainda se mantém, mas o seu caudal tem-se reduzido substancialmente.

Portanto, a verdadeira origem do seu topónimo é um enigma, que permanecerá no segredos dos Deuses. Torre d'Eita, que aparece ao longo dos tempos e chega aos nossos dias, inclusive em documentos lavrados no 
século XX. É ainda da lembrança das gentes desta freguesia a inscrição na estação de caminho-de-ferro e nos seus bilhetes de transporte.

Tudo leva a crer que só desde há muito pouco tempo se tenha passado a escrever Torredeita; no entanto, no subconsciente do povo, perdura ainda a imagem gráfica e, por vezes, ainda se escreve Torre d' Eita.

\title{
Evolução do topónimo
}

\author{
SA N TA MARIA DA TORRE \\ T ORR E D E E I TA \\ T O R R E D' E I T A \\ T O R R E D E I T A
}

No que diz respeito às actividades, as rendas de bilros, o fiar do linho e os teares manuais são antigas indústrias domésticas da freguesia. Existe, ainda, o famoso vinho do Dão que também é oriundo desta terra.

A nível associativo, como refere Fernando Bexiga (1989) no seu livro Torredeita, a Terra e o Homem, existem: o Grupo Recreio e Sport de Torredeita, datado de 1936, que se dedica à actividade desportiva, tendo cerca de 400 associados; a Associação Cultural e Recreativa de Routar e a Associação Desportiva e Cultural de Vila Chã do Monte, fundadas em 1985 e em 1982, respectivamente, que se dedicam ao desporto e à cultura; o Centro Social e Paroquial da Freguesia de Torredeita que é uma Instituição Privada de Solidariedade Social com fins educativos e sociais nesta freguesia e que por sua vez, a Fundação Joaquim dos Santos, aqui estudada, Instituição Privada de Solidariedade Social, fundada em 1967, que tem como fins principais o apoio à criança, ao idoso e à família, a cooperação com outras Instituições de acção social e a realização de fins culturais e educativos.

\subsection{O Papel da Fundação Joaquim dos Santos na Freguesia}

A Fundação Joaquim dos Santos, através das suas valências, nas vertentes educativa, cultural e social, desempenha um papel preponderante no desenvolvimento e no evoluir das suas gentes. É, ao mesmo tempo, o contributo para que Torredeita deixe de ser apenas uma terra simpática, de que "todos" já ouviram falar, para passar a ser uma terra com poderes económicos e de decisão, impondo-se, assim, para além das suas margens no desenvolvimento regional e nacional. 
No que se refere à vertente educativa, talvez a mais importante, há a salientar que esta Fundação foi pioneira nesta região com a criação da Pré-Escola e da Creche, contribuindo para o desenvolvimento da comunidade. A primeira imagem da Fundação deveu-se ao seu impacto no domínio educativo, pois deu-se uma projecção da freguesia para o exterior, mas também para o seu interior. A criação da Escola Profissional de Torredeita, o projecto que ela apresenta aos jovens e a sua aceitação, tanto pessoal como profissional, são factores determinantes no crescimento desta e para o desenvolvimento da região. Por outro lado, a sociedade local é beneficiada, na medida em que permite a criação de empregos directos, conduzindo, desta forma, ao aumento dos seus rendimentos; ou seja, as famílias arrendam as suas casas aos estudantes provenientes de outras localidades e criam-se novas instalações e novos espaços comerciais.

Quanto à vertente social, destaca-se o papel das diversas valências da Fundação que deram cobertura a uma série de áreas, tais como: Lar de Idosos, o apoio às famílias mais necessitadas, através do Apoio Domiciliário; este serviço permite melhorar e superar sobretudo carências alimentares sentidas por muitas pessoas, possibilitando-lhes uma alimentação mais equilibrada e saudável.

No aspecto cultural, há a referir a criação do Rancho Folclórico de Torredeita, que é um autêntico agente cultural e turístico, detentor de um currículo invejável, o mais representativo da Beira Alta, tornando-se a ponte de ligação com diversos povos, de diversas culturas e civilizações. A criação do Ecomuseu, propriedade do Rancho Folclórico de Torredeita, é outro grande atractivo da cultura desta freguesia, onde os visitantes podem apreciar toda a riqueza do seu remoto e variado espólio, bem demonstrativo do património cultural patente em Torredeita. Neste contexto, é quase obrigatório referir a locomotiva que durante 70 anos circulou pela Linha do Dão, servindo Torredeita, sendo uma das suas peças e uma referência valiosa que contribui para dar eco a toda esta vasta riqueza. A recuperação do Lagar de Azeite da Cepeda e, consequentemente, dos seus costumes e tradições tornou-se cartaz de visita para todos aqueles que vêem na cultura um foco de desenvolvimento e enriquecimento de uma região. Com todas as raízes no artesanato, a cooperativa "O Enleio" surge, por uma necessidade, ao dar seguimento a todo um trabalho de desenvolvimento na cultura e para a cultura. Renasce, assim, a produção da renda de bilros e das bonecas serranas, com produção própria e venda das suas "relíquias" nas principais feiras do País e exposições no estrangeiro.

É também no aspecto económico que a Fundação Joaquim dos Santos, através das suas valências, contribui para que o desenvolvimento de Torredeita seja um facto. A Fundação é o maior empregador local dos 
habitantes da freguesia e, além de contribuir para o aumento do nível de vida e do poder de compra das suas gentes, leva-as a fixarem-se, a edificarem e a cultivarem as suas vidas na freguesia. Assim, deixa de existir a deserção da população, aproveitando os recursos humanos nela existentes e, de igual modo, garante-nos a continuidade do trabalho que esta Fundação, ao longo do tempo, tem vindo a desenvolver. Preparando hoje o dia de amanhã, em Torredeita existe a convicção de que esta obra vai engrandecer cada vez mais o respectivo nome e o povo que nela habita e coabita.

Com a consolidação de todas estas realizações, entre outras existentes na freguesia, foi aprovada no dia 25/04/96, em Assembleia da Junta de Freguesia e por unanimidade, a proposta para elevação de Torredeita à categoria administrativa de Vila, mediante Proposta de Lei a apresentar oportunamente na Assembleia da República, para apreciação e aprovação. Como referiu o Sr. Presidente da Junta de Freguesia de Torredeita, Sr. Alberto Ascensão, a Fundação, através das suas valências, detém um papel determinante para a consumação desta aspiração.

Presentemente, esta Fundação e todas as suas valências movimentam diariamente, no seu todo, cerca de 632 pessoas. Este número reflecte, inequivocamente, o contributo e a importância que esta desempenha na freguesia.

\section{A GÉNESE DA OBRA SOCIAL E CULTURAL}

\subsection{Quem foi Joaquim dos Santos?}

Joaquim dos Santos nasceu em 23 de Junho de 1882, no lugar do Casal, uma pequena aldeia da freguesia de Torredeita, filho de Maria Cândida do Espírito Santo. Órfão de tenra idade, fica ao encargo de uma tia que o educa até à idade dos 9 anos. Entretanto, é recebido por um tio, com morada no Porto, onde é maltratado, acabando por viver com um padeiro que o abriga em sua casa, juntamente com os cinco filhos daquele. Frequentou a escola primária no Porto e, com 9 anos, começou a trabalhar, iniciando-se na arte de latoeiro, aprendendo, também com sucesso, a profissão de canalizador.

Joaquim dos Santos passou os últimos anos de vida junto da filha, $\mathrm{Sr}^{\mathrm{a}}$ D. Clementina Santos, actualmente com 85 anos de idade, que não se poupou a esforços para lhe proporcionar um fim de vida tranquilo, apesar de ter sofrido de grande enfermidade, acabando por falecer em 1973, aos 91 anos de idade.

Pode afirmar-se que, como homem de origem modesta, simples, 130 castigado no trabalho, sensivel à miséria, soube aproveitar a fortuna. Joaquim 
dos Santos doou 300000 escudos à Confraria de São Vicente de Paulo para a construção do Bairro Social Vicentino de Torredeita. Este é composto por 12 acolhedoras moradias, que possibilitaram às famílias necessitadas desta freguesia terem uma habitação condigna. Contribuiu, igualmente, para a construção da estrada para a sua terra natal (Casal) e, ainda, para a compra e montagem do relógio da Igreja Paroquial. Mais tarde, comprou e doou um prédio na Amadora, conforme escritura pública de 24/2/1967, e disponibilizou $700000 \$ 00$ em numerário, para a Fundação Joaquim dos Santos. Este prédio, que rendia por mês $10100 \$ 00$, era constituído por seis habitações e duas lojas, que estão arrendadas. Actualmente, este prédio ainda é património da Fundação e está em fase de venda aos inquilinos ${ }^{7}$.

Apesar de viver grande parte da sua vida num meio urbano, não esqueceu o cariz rural e as necessidades sentidas pelas gentes da terra que lhe serviu de berço.

\subsection{O papel do Fundador}

O homem tem a tarefa de criar e desenvolver condições e meios que permitam corresponder a uma sociedade exigente. Talvez por isso, é comum afirmar-se que, do homem, pode sempre duvidar-se, mas é impossível duvidar da sua obra. A Fundação Joaquim dos Santos cresceu e desenvolveu-se graças ao esforço do Sr. Inspector Arcides Simões, conferindo-lhe um lugar destacado no quadro de honra dos Torredeitenses.

Tem contribuído para o enriquecimento, desenvolvimento social e cultural da região, nomeadamente ao impulsionar a criação da Fundação Joaquim dos Santos por incumbência do Sr. Joaquim dos Santos.

Em cumprimento da vontade do Sr. Joaquim dos Santos, e na qualidade de gestor de negócios, o Sr. Inspector Arcides Simões recebe a doação de um prédio de rendimento na Amadora, tendo este sido o primeiro passo para a criação da Fundação Joaquim dos Santos. Prepara e legaliza os estatutos desta Fundação, sendo esta a figura jurídica escolhida para dar prossecução ao projecto. Foi feito um levantamento rigoroso da população existente na freguesia, da constituição dos agregados familiares, da sua situação económica e das suas carências. Paralelamente a este trabalho, foi arrendado um edifício velho onde foram feitas obras de restauro para instalar os primeiros serviços de apoio às famílias e pessoas em dificuldades. Abriu-se um Jardim de Infância, que foi pioneiro no concelho de Viseu, visto estar integrado num meio rural. 
Ao longo dos 30 anos decorridos desde o início deste projecto, o Sr. Inspector tem-se encarregado da Administração da Fundação, promove e acompanha todos os projectos que a ela dizem respeito. Neste projecto que é hoje a Fundação, o Sr. Inspector tem desempenhado um papel activo no quadro organizativo.

Segundo afirma o Sr. Inspector, o projecto, concretizado por esta Fundação, foi realizado com dimensão equilibrada e susceptível de ser ampliada, proporcionando a resposta adequada ao bem-estar das pessoas e ao desenvolvimento local e regional.

\subsection{Conceito de Instituição Privada de Solidariedade Social}

No Inquérito anual feito pelo INE, às Instituições Privadas de Solidariedade Social (IPSS), definem-se estas como Instituições sem fins lucrativos. São constituídas por iniciativa de particulares, com o objectivo de dar expressão organizada ao dever moral de solidariedade e de justiça entre os indivíduos, desde que não sejam administradas pelo Estado ou por um corpo autárquico, com o objectivo de fornecer serviços ou prestação de proteç̧ão social. As prestações podem abranger, de harmonia com os fins próprios de cada uma das Instituições, actividades de protecção à infância e juventude, à família, comunidade e população activa, aos idosos e aos deficientes, bem como outras acções cuja inclusão seja valorizada por despacho do Ministério do Emprego e Segurança Social.

Peter F. Drucker, na sua obra As Organizações Sem Fins Lucrativos (1990), refere que "a organização sem fins lucrativos existe para produzir uma mudança nos indivíduos e na sociedade e para cumprir os seus objectivos"8. À semelhança das organizações que visam a obtenção de lucros, as organizações sem fins lucrativos também têm objectivos e metas pré-estabelecidas. A missão deste tipo de organizações é de longo alcance, uma vez que existem para prestar um serviço à comunidade.

As IPSS, uma vez registadas na Direcção Geral da Segurança Social, adquirem automaticamente a natureza de pessoas colectivas de utilidade pública, revestindo uma das formas a seguir indicadas: ${ }^{9}$

- Associações de Solidariedade Social;

- Associações de Voluntários de Acção Social;

- Associações de Socorros Mútuos;

- Fundações de Solidariedade Social;

- Irmandades da Misericórdia. 
Estas instituições podem ainda agrupar-se em Uniões, Federações e Confederações.

De uma forma geral, as Instituições, para além das receitas próprias, são subsidiadas pelo Estado, por intermédio da Segurança Social, no quadro de acordos de cooperação, ou sob a forma de subsídios eventuais.

Por valência entende-se a resposta social organizada com vista a satisfazer determinadas necessidades dos utentes. No âmbito das áreas de cooperação, as IPSS desenvolvem as suas actividades nas áreas da infância e juventude; família e comunidade; invalidez; reabilitação e terceira idade, sendo a sua acção predominante nos domínios do apoio à criança, aos jovens e à terceira idade.

De acordo com o plano de contas vigente nestas Instituições, as valências foram classificadas nas seguintes funções: ${ }^{10}$

\section{Função Velhice}

A velhice corresponde ao facto de se ter atingido uma certa idade mínima a partir da qual, na maior parte dos casos, se pode cessar a actividade profissional principal.

\section{Valências:}

Lares de $3^{\mathrm{a}}$ idade; centros de dia; centros de convívio; residências para pessoas idosas; apoio domiciliário.

\section{Função Família}

Compreende todas as prestações que têm por objecto os encargos resultantes da educação de crianças e, eventualmente, quando a legislação o preveja, o sustento de outros membros da família (cônjuge, ascendente, etc.).

\section{Valências:}

Creches e jardins de infância; actividades de tempos livres; colónias de férias; outras.

\section{Função Invalidez/Enfermidade}

A Invalidez/Enfermidade (física ou mental) é a inaptidão para exercer uma actividade de determinado grau ou para levar uma vida social normal, quando for provável que esta inaptidão seja permanente, ou ainda quando ela permanecer para além de um certo período de tempo, de acordo com o definido na legislação relativa à cobertura do risco "doença". 


\section{Valências:}

Centro de reabilitação para cegos; centros de apoio pelo trabalho; centros de apoio ocupacional; apoio domiciliário; outras.

\section{Função Indigência}

Esta função compreende as prestações concedidas independentemente de uma causa, ou de uma situação de facto, entendida no sentido das outras funções, num estado comprovado de carência de recursos.

\section{Valências:}

Refeitórios; albergues nocturnos; acções de apoio a desalojados; auxílios prestados a indigentes; outras.

\section{Função Doença}

A doença, no sentido estrito deve entender-se como uma alteração mais ou menos profunda da saúde, afectando em geral a integridade física ou mental dos indivíduos.

\section{Valências:}

Internamento hospitalar; assistência hospitalar; consultas médicas; medicamentos; outras.

\section{Função Diversos}

Esta função compreende as prestações de proteç̧ão social que não podem ser classificadas noutras funções.

\section{Valências:}

Acções de apoio a toxicodependentes; acções a favor da reinserção de delinquentes; assistência a vítimas de violência; outras.

\subsection{Apresentação da Instituição Inserida nas Várias Vertentes}

A Fundação Joaquim dos Santos surgiu em 1967 e teve os seus estatutos aprovados em 1965 e revistos em $1983^{\prime \prime}$.

São 6rgãos da Instituição o Conselho Geral dos Amigos da Fundação, o Conselho de Administração e o Conselho Fiscal. A Gerência desta 
Instituição é exercida pelo Conselho de Administração e pelo Conselho Fiscal. A Fundação é representada pelo Presidente do Conselho de Administração, Sr. Inspector Arcides Simões.

ESQUEMA DOS ÓRGÃOS ADMINISTRATIVOS

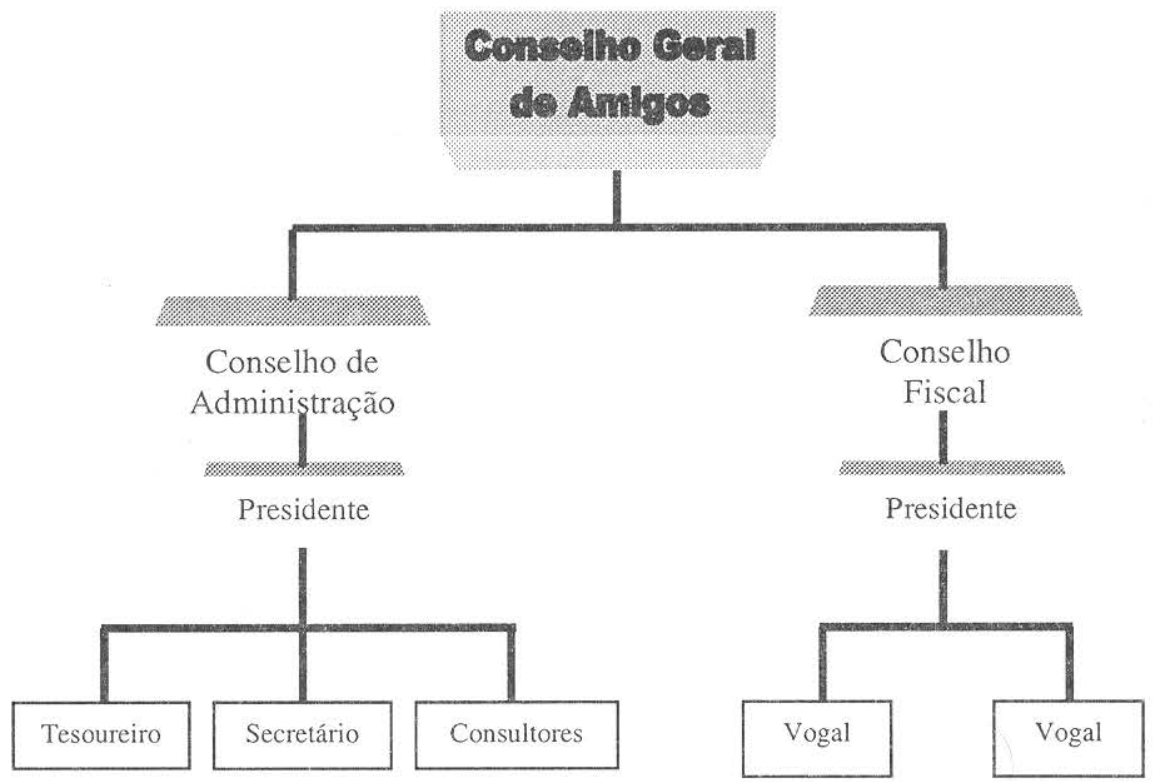

Esta Instituição está registada na Direcção Geral da Segurança Social ${ }^{12}$. É, pois, reconhecida, apoiada e subsidiada. A Instituição recebe assistência financeira concedida periodicamente pelo Ministério da Solidariedade Social, através de acordos de cooperação. $\mathrm{O}$ facto de ser tutelada e subsidiada pelo Estado não lhe faz perder a sua natureza privada, nem o direito de livre actuação.

A Fundação prossegue os seguintes objectivos:

- assistência médica e medicamentosa;

- protecção às crianças e pessoas idosas da freguesia, em regime de semi-internato e internato;

- auxílio familiar por distribuição de subsídios;

- cooperação com quaisquer Instituições de acção social;

- realização de fins culturais e educativos 
O apoio à criança traduz-se na existência de uma Creche e Jardim de Infância e ainda de um Centro de Actividades de Tempos Livres.

A protecção ao idoso e o auxílio familiar são levados a cabo pelas valências de Lar e Apoio Domiciliário. Isto só é possível devido à cooperação com outras Instituições de acção social, nomeadamente na assistência médica e medicamentosa, tanto a crianças como a idosos.

A Escola Profissional de Torredeita, cuja entidade promotora é também a Fundação Joaquim dos Santos, foi criada no âmbito da prossecução dos fins educativos.

Desenvolve igualmente actividades culturais, nomeadamente através de protocolos estabelecidos com o Rancho Folclórico de Torredeita e o seu Ecomuseu.

Esta Fundação foi também entidade dinamizadora e hospedeira da Cooperativa de Artesanato da renda de bilros e trajes regionais "O Enleio", actividade de raiz predominantemente popular e de forte expressão na região.

A Fundação Joaquim dos Santos tem em pleno funcionamento:

- creche e jardim de infância, com a frequência de 120 crianças;

- centro de actividades de tempos livres, com a frequência de 30 crianças;

- lar e apoio domiciliário para 50 idosos; 
ESQUEMA DA FUNDAÇÃO E SUAS VALÊNCIAS

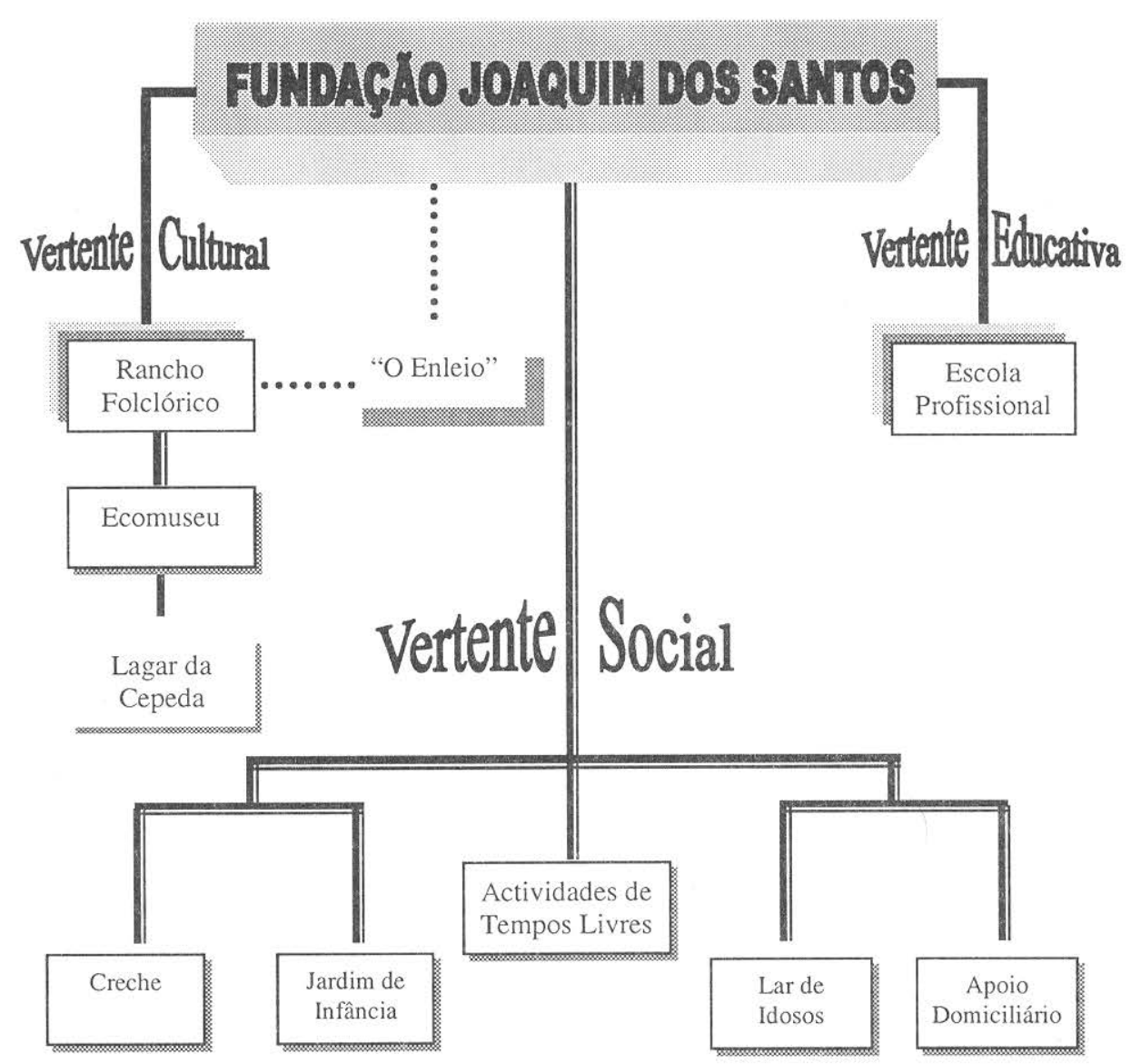

- tem um protocolo de cooperação com o Rancho Folclórico de Torredeita, pessoa colectiva de utilidade pública, com relevante projecção no País e no estrangeiro, no âmbito da cultura portuguesa, designadamente através do seu Ecomuseu e do Grupo de Danças, Cantares e Trajes;

- dentro do espírito de preservação das actividades tradicionais, foi entidade hospedeira da Cooperativa de Artesanato "O Enleio";

- foi promotora da Escola Profissional de Torredeita. 
Cada valência nasceu no seu tempo e em espaço próprio, com objectivos bem claros, com os mesmo cuidados organizacionais de crescimento, de qualidade, de concepção e de consolidação de fontes de financiamento.

\section{O ASPECTO CULTURAL}

\subsection{Rancho Folclórico de Torredeita}

O Rancho Folclórico de Torredeita foi fundado em 1963 pelo seu director técnico, o Sr. Inspector Arcides Simões. É pessoa colectiva de utilidade pública, nos termos do Dec.-Lei n. ${ }^{\circ} 460 / 77$, de 7 de Novembro ${ }^{13}$.

Este Rancho ostenta a beleza das características etnográficas da Beira Alta nos seus trajes, cantigas e danças populares; é apreciado aquém e além fronteiras; é um agrupamento reconhecido pela qualidade do seu reportório, pela disciplina e pelo rigor tradicional que enforma as suas actuações. No livro Folclore (1971), de Pedro Homem de Mello, é feita alusão ao notável valor do Rancho Folclorico de Torredeita: "eis o que nos leva a reconhecer no Rancho de Torredeita um valor de bandeira nacional"14.

Ao fundar este Rancho, o Sr. Inspector Arcides pretendeu salvar as formas e expressões da sua zona, pois, em sua opinião, "o Folclore não é um futuro sepultado, mas uma jóia de alto preço com o sortilégio do movimento perpétuo incorporando os traços sociopsicológicos do meio onde vive". Daí nos revelar o modo de ser e, principalmente, o modo de viver da terra e das gentes, na qual muita coisa desaparece e muitas outras surgem numa fusão entre o tradicional e o nascente.

O Rancho Folclórico de Torredeita é genuinamente beirão; tanto o coro como as danças têm um ar e uma beleza típicos da região. Nas suas actuações, são bem visíveis alguns dos aspectos culturais que o rodeiam, enriquecendo as suas actuações com as rendeiras da Cooperativa "O Enleio", a executarem as rendas de bilros. São também visíveis as bonecas serranas e algumas peças do Ecomuseu.

Este Rancho Folclórico é constituído por elementos com profissões heterogéneas, cujas idades variam entre os 14 e os 70 anos.

Segundo indicações recolhidas, este Rancho, com a sua actividade ininterrupta, tem-se exibido por diversas vezes, em inúmeras regiões do País; actuou 15 vezes em programas para a Televisão Portuguesa; e representou Portugal em vários países da Europa, no Mar Báltico, e na América do Sul, calculando-se em cerca de 180 representações, sendo duas delas para a televisão espanhola. Foi também recebido por duas vezes por Sua Santidade o Papa. 
Este Rancho, ao longo do seu riquíssimo historial, obteve diversas distinções de mérito, entre as quais se contam: a Medalha de prata da Cidade de Viseu; o Grande Colar de Bronze do Festival Internacional de Dijon, França; o Troféu Mundial do Folclore de Anemasse, França. É sócio honorário da Casa de Viseu, no Rio de Janeiro; é sócio fundador da Federação de Folclore Português; e possui, ainda, quatro discos editados pelas etiquetas: $\mathrm{St}^{\circ}$ António, Alvorada, Triunfo e Tecla.

Criou o primeiro Ecomuseu rural na freguesia, com o qual se propõe explicar, através da Ecologia e da vida tradicional das populações, as potencialidades da região; e, finalmente, colabora ainda na promoção de programas de formação profissional na arte da renda de bilros.

\title{
Alguns cantares do Rancho Folclórico de Torredeita ${ }^{15}$
}

\author{
Serraninha \\ Os homens: \\ "Serrana se queres dançar \\ vai ter ao pomar \\ que eu lá irei ter" \\ As mulheres: \\ "Sim, senhor, \\ eu da serra sou \\ eu bailar não vou \\ mas gosto de ver"
}

A Serraninha é um dos muitos temas interpretados por este Rancho, mas existem outros, como sejam, Macieira do Adro e Talo da Vide Chora. A apresentação deste género de musicalidade é feita por um membro do Rancho, através duma pequena introdução, realçando a beleza e encantamento com sabor medieval. A propósito dos temas: Entrar ao Meio; Indo Eu, Indo Eu a Caminho de Viseu; Se Eu Andasse a Namorar; Ora Doba Dobadoira Doba; Palmas ao Meio; Hei-de Pedir à Virgem e Enleio, o Sr. Inspector Arcides Simões, numa recente actuação do Rancho e fazendo alusão a estes temas, dizia: “...o Folclore em Torredeita tem o culto da lógica. Tudo nas suas danças obedece a marcações impostas pelo significado das palavras ...".

Este projecto cultural, que tem galvanizado gerações de Torredeitenses, foi sem dúvida a génese de todo o desenvolvimento sociocultural que hoje se opera nesta freguesia. Este agrupamento é o emblema de Torredeita, de Viseu e da Beira Tradicional. 


\subsubsection{Ecomuseu}

Acerca do termo "Ecomuseu", começo por fazer uma pequena abordagem à Etnografia. Segundo Leite Vasconcelos, em Etnografia Portuguesa (1980), esta é "o estudo do povo no que toca ao mais saliente da sua personalidade física e psíquica, às suas divisões, classes,... suas tradições orais e objectivas, ao seu "habitat", sob o aspecto natural e histórico, tanto quanto baste para a nítida compreensão ou interpretação da vida tradicional ..."16.

Etnografia é, portanto, o estudo do que é característico e popular, as raízes, com muitas determinantes desde a poesia, à música, aos hábitos, aos objectos, ao próprio povo e à sua linguagem, bem como o devido valor à terra.

Tal como disse o professor Georges H. Riviére, o "Ecomuseu é o espelho onde a população se contempla para nele se reconhecer ... é o que a população mostra aos seus hóspedes para que estes a compreendam melhor, no respeito pelo seu trabalho, pelo seu comportamento, pela sua intimidade ..."17.

Para além disso, o Ecomuseu conduz-nos à região e à comunidade, através da sua função social e didáctico-pedagógica do ambiente e da dinamização do povo que representa.

O Ecomuseu explica a Ecologia da região, a vida tradicional das populações, o uso dos materiais para a confecção dos utensílios, ferramentas e outro artesanato. Ao mesmo tempo, é um local de estudo e de coordenação. Pode ainda ser considerado uma escola que ajudará à formação de especialistas em artesanato.

O Rancho Folclórico de Torredeita efectuou uma recolha de peças antigas, objectos fora de uso, independentemente do seu estado de conservação, com o objectivo de preservar a cultura da região e de dar a conhecer as suas raízes. Todo este dinamismo ultrapassou as expectativas, devido ao elevado número, à qualidade e à diversidade das peças. A recolha foi mais do que suficiente para a utilização destas peças nos programas de cantares, conferindo-lhes condições para desenvolver um parque etnográfico. Nesta linha, nasce, então, o Ecomuseu de Torredeita, propriedade do Rancho Folclórico.

O Ecomuseu não é uma figura jurídica, é um espaço, forma de designar um conjunto de peças culturais que são utilizadas pelo Rancho Folclórico nas suas actuações e estão à disposição de quem vê neste riquíssimo espólio toda a cultura e tradições de um povo.

Esta vertente museológica é "sui generis", pois encontra-se no seu espaço próprio, no local onde cada peça transmite o seu real significado, função e utilidade. Combate-se aqui a ideia de museu como mera "sala de exposições", 
restrita e limitada por 4 paredes; defende-se, pelo contrário, a ideia de um museu amplo e diversificado em espaços.

Assim sendo, este Ecomuseu conta já com cerca de 600 peças entre as quais: Lagares de vara; moinhos de farinha; alambique de destilar aguardentes; fábrica da cera; locomotiva a vapor de caminho-de-ferro; carros de bois de diversos tipos e seus pertencentes (charruas, arados, grades ...); tractor antigo; máquinas de serrar madeira; engenhos; estanca rios; cabaços; diversos utensílios domésticos, musicais e botica; Lagar de azeite (Cepeda).

A grande maioria destas peças já se encontram recuperadas, sendo possível apreciar toda a sua beleza; outras aguardam que mão mestra as faça renascer para longa vida.

O Ecomuseu vai estendendo os seus tentáculos por uma vasta região e espalha-se por toda a área Torredeitense.

\subsubsection{O Lagar de Azeite da Cepeda}

O Lagar de Azeite da Cepeda, também designado por Lagar "Ernesto Leitão Cardoso", foi doado, em 1982, ao Rancho Folclórico de Torredeita e encontra-se situado junto à estrada que liga Torredeita a Vila Nova.

Segundo um trabalho realizado pelo núcleo de professores a tempo inteiro da Escola Profissional de Torredeita, existe uma data gravada numa das pedras deste Lagar que remonta a 1837 (terá, assim, pelo menos 161 anos); presume-se, no entanto, que esta data tenha sido de uma reconstrução e que a sua construção inicial tenha sido anterior, em data desconhecida. O processo em que se baseia o Lagar da Cepeda remonta ao tempo de Arquimedes (287-212 a. C.). O Lagar de Azeite da Cepeda fazia a produção do azeite através da energia hidráulica, sendo a água proveniente de duas represas de um regato que corre por perto.

Vários grupos nacionais e estrangeiros que visitam o Ecomuseu têm sido presenteados com a visita a este Lagar e com o ambiente que lhe é próprio, com pratos típicos da gastronomia regional, que constituíam as refeições dos trabalhadores dos lagares de azeite e dos agricultores que ali passavam muito tempo, vendo "nascer" o precioso e saboroso azeite extraído das negras azeitonas.

São servidos no Lagar de Azeite da Cepeda os deliciosos aperitivos: queijo de ovelha; rojões; morcela; chouriça assada na brasa; azeitonas; pão de milho e centeio; vinho do Dão e os seguintes pratos: caldo verde; migas (batatas, bacalhau e cebolas assadas no borralho), regadas com o azeite; o 
cabrito assado na brasa; a vitela assada no pau de loureiro. Serve-se ainda a fruta da região e o requeijão com mel.

É, sem dúvida, o preservar de uma excelente e rica gastronomia regional, reflectindo a pureza, a originalidade e a simplicidade das refeições dos nossos antepassados que se devem guardar e manter vivas ao longo dos tempos.

\subsection{3. "O Enleio"}

A Cooperativa de Artesanato da Renda de Bilros e Trajes Regionais, "O Enleio", foi criada para dar continuidade a todo um trabalho em prol do artesanato da região, nomeadamente das rendas de bilros e dos trajes regionais. "O Enleio" surge com 12 sócias, tendo entrado com uma quota de $5000 \$ 00$ cada uma. Funcionando nas instalações do Rancho Folclórico, na antiga estação de caminho-de-ferro, agora desactivada, as rendeiras (sócias) começaram, então, a dar forma e vida à Cooperativa. Assim, "O Enleio" projecta-se na cultura do Rancho Folclórico de Torredeita e do seu Ecomuseu.

Estas rendas, "típicas dos lugares piscatórios (onde há redes há rendas, lá diz o ditado), chegaram a Torredeita via Farminhão, aldeia situada a cerca de $5 \mathrm{Km}$, para onde foram trazidas por uma senhora que tinha aprendido em Peniche, segundo processo que terá cerca de 100 anos" ${ }^{\text {"18 }}$.

A Cooperativa "O Enleio" começa, então, a ter produção própria. Esta Cooperativa fornece, às rendeiras que são sócias, as linhas e os modelos para as rendas de bilros, que podem ser, ou não, confeccionadas por encomenda. As rendeiras produzem $\mathrm{e}$ vendem à Cooperativa, mediante tabela previamente estabelecida. Por sua vez, a Cooperativa "O Enleio" é que vende ao público em geral. Cada sócia tem que dar um rendimento mínimo mensal de $12000 \$ 00$ à Cooperativa; em contrapartida, esta efectua-lhes o pagamento para o Centro Regional da Segurança Social.

Além das vendas efectuadas nas principais feiras do País e em exposições no estrangeiro, destaca-se um posto de venda na cidade de Lund, Suécia, mercê do empenho manifestado por três suecas que visitaram Torredeita, as quais, encantadas com o que viram, se prontificaram a comercializar os produtos no seu país, passando estes a ser regularmente enviados pela Cooperativa "O Enleio".

Para a sua produção, "O Enleio" repescou modelos de rendas antigas e introduziu modelos totalmente novos, oriundos da tradição da terra e inspirados na natureza. Podemos observar imensas estilizações de flores 
(malmequeres, miosotis), de espigas, folhas, e algumas árvores. Aparecem também círculos e arcos concêntricos, losangos e quadrados. A renda, depois de concluída, é colocada numa peça de linho ou em qualquer outro pano, como, por exemplo: em dobras de lençol, toalhas de altar, lencinhos de bolso, toalhas de baptizado, jogos de sala ou centros de mesas.

As rendas de bilros são "executadas sobre piques, desenho picotado sobre cartolina, que referencia os pontos onde a rendeira deve pregar os alfinetes que fixam o trabalho à almofada, orientando a disposição dos fios no trabalho"19.

É utilizado um grande número de fios enrolados em bilros. Normalmente trabalham-se quatro bilros de cada vez, dois em cada mão.

Outra actividade a que se dedica a Cooperativa "O Enleio" é a produção e comercialização das bonecas serranas. Estas são uma cópia em miniatura dos trajes originais, tanto do homem como da mulher, do Rancho Folclórico de Torredeita. São, também, produzidas pelas rendeiras, nas mesmas condições que as rendas de bilros. Na sua confecção nada é deixado ao acaso, na medida em que têm em conta todos os pormenores, desde as chinelas ou tamancos, às meias até ao lenço e à capucha.

$\mathrm{Na}$ mencionada Cooperativa ainda se podem encontrar alguns produtos artesanais oriundos da região, como, por exemplo: vassouras em palha, tamancos e capuchas. Fabricam também, por encomenda, trajes destinados a outros ranchos.

Segundo palavras da vice presidente da Cooperativa "O Enleio", Sr. ${ }^{a}$ Rosa Monteiro, "a qualidade e o sucesso destes produtos estão nos materiais utilizados, mas sobretudo na técnica própria e exclusiva da sua produção".

\section{A VERTENTE SOCIAL}

\subsection{Creche e Jardim de Infância}

O trabalho a realizar ao longo do ano com as crianças pretende atingir os seguintes objectivos:

- favorecer individual e colectivamente as capacidades de expressão, comunicação e criação, estimulando a sua formação e o desenvolvimento equilibrado de todas as suas potencialidades;

- contribuir para a estabilidade e segurança afectiva da criança;

- incutir hábitos de higiene e de defesa da saúde pessoal e colectiva;

- desenvolver progressivamente a formação moral da criança, a autonomia e o sentido de responsabilidade; 
- fomentar gradualmente a integração em actividades de grupo como meio de aprendizagem e factor de desenvolvimento da sociabilidade e solidariedade;

- despertar a curiosidade pelos outros e pelo meio ambiente, de modo a permitir uma melhor integração e participação da criança;

- assegurar uma participação efectiva e permanente das famílias no processo educativo, mediante as convenientes interacções de esclarecimento e sensibilização.

A Creche destina-se a todas as crianças, dos 6 meses aos 3 anos de idade, e o Jardim de Infância àquelas com idades compreendidas entre os 3 e os 6 anos de idade. As inscrições obedecem a alguns critérios, dando-se prioridade às crianças de Torredeita e da região de Viseu, mas sobretudo às famílias que apresentem condições socioeconómicas desfavoráveis.

\subsection{Centro de Actividades dos Tempos Livres}

Os centros de actividades dos tempos livres pretendem dar uma ocupação às crianças depois do horário escolar, tendo como objectivos:

- possibilitar às crianças, fundamentalmente às do meio rural envolvente,

o contacto com realidades diferentes que o sistema escolar ainda não lhes permite;

- permitir à criança o contacto com novos espaços e novas regiões;

- auxiliar a criança a descobrir tudo aquilo que tem dentro de si e que a rodeia;

- complementar as actividades escolares e apoiá-las nas áreas que escapam aos pais, quer por falta de tempo, quer por falta de formação;

- fomentar o espírito de grupo.

Destina-se a todas as crianças do $1^{\circ}$ e $2^{\circ}$ ciclo. As inscrições obedeceram a alguns critérios, dando-se prioridade à naturalidade/residência e às famílias que apresentem condições socioeconómicas desfavorecidas.

\subsection{Lar e Apoio Domiciliário}

A Fundação Joaquim dos Santos, ao desenvolver uma valência de Lar e Apoio Domiciliário, tem como objectivos: 
- proporcionar uma vida em consonância com os princípios da liberdade e da dignidade e que conduza ao bem estar físico, mental, social e espiritual;

- contribuir para que o utente se sinta no seu próprio ambiente em tudo aquilo que o rodeia;

- utilização do potencial e da experiência das pessoas idosas nas actividades a desenvolver, contribuindo para um melhor aproveitamento e ocupação dos tempos livres;

- fomentar o espírito de grupo e um ambiente de família;

- facultar ao idoso as condições para enfrentar com alegria e optimismo a vivência de uma nova etapa na sua vida envelhecimento saudável.

\section{Lar}

Destina-se a todos os idosos reformados ou deficientes não acamados, que reunam as seguintes condições:

- idade superior a 65 anos;

- não tenham familiares que os integrem no seu seio e sintam de um modo particular a solidão;

- não sejam portadores de doenças infecto-contagiosas.

No que respeita às actividades na valência de Lar, estas subdividem-se em três áreas:

\section{Fins Socioculturais}

- criação de um espaço de leitura/biblioteca, com os recursos adequados;

- participação em acções de formação/sensibilização, promovidas pelas Instituições culturais locais e outras;

- realização de passeios, piqueniques, festas convívio, jogos;

- participação nos movimentos culturais locais (Ecomuseu, Rancho Folclórico).

\section{Físicas}

- organização de roteiros pedestres;

- criação das condições para a realização de pequenas actividades domésticas e agrícolas, de acordo com a apetência de cada um.

\section{Objectivos Religiosas e Espirituais}

- participação em celebrações religiosas. 


\section{Apoio Domiciliário}

Destina-se a todos os idosos que queiram permanecer em suas casas por razões de afectividade, mas que necessitem de um apoio alimentar, de higiene pessoal, habitacional e de tratamento de roupas. Este apoio poderá prestar-se também a não idosos, desde que revelem uma situação que necessite deste tipo de serviços (por motivos de doença, ausência temporária de familiares, entre outros).

A alimentação dos utentes, que recebem o apoio em suas casas, envolve o fornecimento de uma refeição diária completa (o almoço) e ainda um lanche. Para os utentes que expressamente o solicitarem, poderá também ser servido o pequeno almoço e o jantar.

É assegurada a higiene pessoal a todos os utentes incapacitados de o fazerem sozinhos. Este serviço é feito por equipas de duas pessoas, em dias e horas a combinar.

A higiene habitacional é feita de acordo com as necessidades dos utentes (chão, po, casa de banho, ...), uma vez por semana, por equipas de duas pessoas.

É assegurado o tratamento de todo o tipo de roupa (lavagem, passagem a ferro e pequenos arranjos de costura), que é recolhida uma vez por semana e entregue, também, semanalmente.

O utente tem sempre assegurado o transporte aos equipamentos médico-sociais locais e é apoiado por serviços de enfermagem, em condições a estabelecer.

É incrementado o contacto entre todos os utentes, dando-lhes a possibilidade de participarem em algumas actividades desenvolvidas no Lar, nomeadamente em passeios para fora da região, participação em actividades culturais desenvolvidas localmente, etc.

Pode ainda ser colocado em cada casa um dispositivo telefónico que permitirá o contacto permanente a qualquer hora com o Lar, onde está sempre alguém disponível para o(a) ouvir e também para o(a) socorrer numa situação de emergência.

\section{RELAÇÃO SOCIOCULTURAL-ESCOLA PROFISSIONAL DE TORREDEITA}

\subsection{Identificação}

A Escola Profissional de Torredeita - E.P.T. foi criada em $1989^{20}$.

Esta Escola enquadra-se nos objectivos do Sistema Educativo e adopta o modelo alternativo ao Sistema do Ensino Regular. É pessoa colectiva de fins 
não lucrativos ${ }^{21}$. A Escola Profissional de Torredeita é de natureza privada, goza de autonomia pedagógica, administrativa e financeira. Exerce a sua função por tempo indeterminado, garantindo sempre a execução completa de cada plano de estudos iniciado.

A sua estrutura orgânica compreende:

- Direcção;

- Conselho Coordenador pedagógico;

- Gestor Administrativo e Financeiro.

Partiu-se do pressuposto de que Torredeita dispõe de um excelente património para a formação sociocultural, de recursos humanos qualificados para a componente científica e prática, bem como de uma situação geográfica privilegiada, num meio rural ávido de progresso e relativamente próximo dos centros urbanos de Viseu e Tondela.

Esta Escola Profissional, tendo como promotora a Fundação Joaquim dos Santos, com grande relevo e importância pela sua acção multifacetada, dá a Torredeita um lugar de destaque no panorama concelhio, distrital, nacional e mesmo internacional, designadamente na área da cultura e da formação profissional, no âmbito do protocolo com o Centro de Formação de Furstenwalde - Alemanha.

A Escola tem à sua disposição estruturas físicas adequadas, amplas e de qualidade, para a realização do projecto educativo e os meios logísticos necessários para um excelente desempenho das acções a efectuar ou em curso. Dispõe de amplas e modernas salas de aula, biblioteca, meios audiovisuais, sala de informática, laboratório de electrónica e electricidade e um moderno auditório com 200 lugares, campos de jogos e mata envolvente para recreio. Para além do refeitório, existe um acolhedor recinto de convívio com bar e instalações destinadas às actividades da Associação de Estudantes.

\subsection{Cursos e níveis de formação}

A frequência da Escola Profissional de Torredeita é facultada a jovens que concluíram o $9^{\circ}$ ano do Ensino Básico ou que tenham abandonado o Ensino Secundário - nível III da União Europeia ou a iniciação profissional com a exigência do $6^{\circ}$ ano de escolaridade-nível II da União Europeia.

A E.P.T. fornece 3 tipos de formação: uma Formação Tecnológica e Prática; uma Formação Científica e uma Formação sociocultural para todos os cursos que são leccionados. Assim, estão criados os seguintes cursos: 


\section{Nível III da União Europeia}

- Técnico de Contabilidade

- Técnico de Construção Civil:

- Condução de Obras

- Topografia

- Medições e Orçamentos

- Desenho

- Técnico de Serviços Comerciais

- Técnico de Animador Sociocultural/Assistente Familiar

- Técnico de Higiene e Segurança no Trabalho e Ambiente

\section{Nível II da União Europeia}

- Operadores de Electricidade

Em termos de procura social, observa-se que a Escola cumpre os seus objectivos em termos de equilíbrio local e regional, da promoção da condição educativa do meio, de factores de desenvolvimento, de cobertura de formação em áreas onde faltam recursos humanos qualificados.

Em termos de área de formação, apresenta uma grande diversidade, numa clara vontade e propósito de satisfazer necessidades e dimensões sociais de trabalho.

\subsection{Outros Aspectos}

A Escola Profissional de Torredeita iniciou a sua actividade no ano lectivo de 1989/90, com 45 alunos e hoje tem matriculados 345 , distribuídos por 15 turmas, naturais dos distritos de Viseu, Guarda e Coimbra e de África, nomeadamente de Cabo Verde.

O projecto educativo desta Escola é renovado todos os anos e tem como finalidade desenvolver, consolidar e sensibilizar os alunos para a nossa realidade de país e de povo.

Esta Escola promove uma valorização sistemática ligada ao meio empresarial público e privado, em conexão com a necessidade, confiança e especificidade da formação de alta qualidade, já avaliada positivamente pela Inspecção Geral de Educação que afirma, sem qualquer dificuldade, "que se trata de uma Escola em que os indicadores recolhidos reflectem organização, disciplina, qualidade - o que será motivo para satisfação não só da estrutura e da Comunidade Educativa e dos seus principais responsáveis, mas do próprio sistema" ${ }^{\text {22 }}$. 
Dos 197 jovens diplomados por esta Escola, têm conseguido emprego qualificado, no sector Público e Privado, cerca de $73 \%$; $15 \%$ prosseguem estudos no Ensino Superior; os restantes 12\% encontram-se a cumprir serviço militar ou em outras actividades de realização pessoal ou ainda emigrados em países da União Europeia, como podemos constatar no gráfico seguinte.

\section{INSERÇÃO DOS ALUNOS NA VIDA ACTIVA PÓS-FORMAÇÃO}

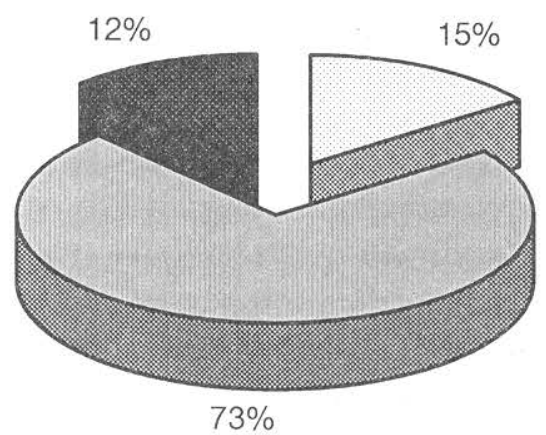

$\square$ Via Ensino $\square$ Via Profissional : Outras Situações

Fonte: E.P.T. - Dados relativos ao ano de 1994/95.

Com a preocupação permanente de optimizar condições para uma boa integração, a Escola Profissional de Torredeita assegura aos seus alunos um subsídio de transporte e/ou alojamento e, no seu refeitório, fornece a refeição do almoço.

A Escola Profissional de Torredeita, em conjunto com o Ecomuseu do Rancho Folclórico de Torredeita, realiza a "Festa da Oliveira", na última semana de Março de cada ano, no sentido de dar a conhecer a cultura tradicional.

Constituem receitas desta Escola as dotações provenientes: da entidade promotora, Fundação Joaquim dos Santos; das propinas de matrículas de frequência; do financiamento proveniente de fundos nomeadamente do PRODEP e do FEDER; e de dois acordos de cooperação com o Ministério da Solidariedade e um contrato programa com o Ministério da Educação. 


\section{PERSPECTIVAS FUTURAS}

\subsection{Projecto do Comboio Histórico e Turístico}

O Rancho Folclórico de Torredeita e a Fundação Joaquim dos Santos debatem-se pela cedência do troço ferroviário compreendido entre as antigas estações de Figueiró, Torredeita e Farminhão, para a concretização do projecto do Comboio Histórico e Turístico.

O troço com uma extensão de $9 \mathrm{Km}$, cheio de elementos enriquecedores, não apenas para o turismo, mas igualmente tendo em vista a salvaguarda de um património que urge preservar (algumas pontes, um pequeno túnel, trincheiras e taludes de grande dimensão), da antiga linha ferroviária do Dão, desactivada em finais da década de 80 e que fazia a ligação entre Viseu e Santa Comba Dão (com posterior acesso à linha da Beira Alta).

Esta iniciativa conta com o apoio da Junta de Freguesia e dos respectivos Órgãos Municipais. Numa sessão ordinária da Assembleia Municipal de Viseu, o Sr. Inspector Arcides Simões propôs à Autarquia que se una ao projecto que Torredeita quer levar em frente, incluindo-o no âmbito das suas actividades culturais e turísticas, bem como contribuindo com recursos teóricos, de equipamento e outros possíveis e adequados à projecção do evento, tendo sido aprovado por unanimidade.

Pretende-se, pois, organizar uma nova infra-estrutura turístico-cultural que proporcione pequenas viagens de recreio, fomente a ocupação de tempos livres e lazer e possibilite o estudo e preservação do património ferroviário nacional. Isto mesmo foi dado a conhecer através de um documento ao Presidente do Conselho de Gerência da Companhia Portuguesa dos Caminhos de Ferro, pelo Sr. Inspector Arcides Simões.

Para reforçar o interesse deste projecto, os seus proponentes contam com o apoio da Associação Portuguesa dos Amigos dos Caminhos de Ferro (APAC) e da Federação Europeia de Caminhos de Ferro Turísticos e Históricos (FEDECRAIL), com sede em Bruxelas. Esta última chegou mesmo a referir à comunicação social que Portugal é o único país da União Europeia que não possui um caminho-de-ferro cultural e turístico.

\section{CONCLUSÃO}

Percorrendo este trabalho, damo-nos conta de que é o homem que faz a História e a História faz ressurgir o homem. 
A Fundação Joaquim dos Santos, sendo uma IPSS (Instituição Privada de Solidariedade Social), tem por objectivo contribuir para a promoção da população da freguesia de Torredeita e ainda da região de Viseu.

Para a realização dos seus objectivos, a Instituição propõe-se, entre outras, manter as seguintes actividades:

- protecção às crianças e idosos em regime de semi-internato;

- assistência médica e medicamentosa;

- cooperação com outras Instituições de acção social ou cultural, afectas ao Estado ou ao sector Privado ou Cooperativo;

- realização de fins educativos e culturais.

As Instituições/Associações que fazem parte da Fundação dispõem de meios próprios, com razoável património para garantir uma vida sustentada na estabilidade e no crescimento, como é o caso d' "O Enleio" e do Rancho Folclórico de Torredeita.

$\mathrm{Na}$ verdade, nota-se que o modelo de cooperação entre a Fundação, o Ecomuseu do Rancho Folclórico e a Cooperativa "O Enleio" está muito bem conseguido e com resultados francamente positivos.

Como é notório, esta Fundação é detentora de um campo largo e diversificado de acção, uma vez que está presente nos vários domínios, designadamente o social, o cultural e o educativo.

É igualmente de salientar que a Fundação Joaquim dos Santos e o Rancho Folclórico de Torredeita são os responsáveis pela promoção e divulgação a nível regional, nacional e internacional do património cultural e das tradiçôes patentes em Torredeita.

Pode concluir-se que a Fundação funciona como se fosse a "mãe", vai tendo os seus "filhos" e vai-lhes dando autonomia para que eles cresçam e se desenvolvam, mas tendo como base quem lhes deu a vida - A Fundação Joaquim dos Santos.

Esta Fundação trouxe vários benefícios à região e às suas gentes, podendo trazer ainda muitos mais, visto que tem registado um crescimento acentuado nas suas diversas valências, o que indica que as perspectivas futuras são de continuidade deste projecto, de desenvolvimento local e regional.

Trata-se, sem dúvida, de um património inestimável. Esta Instituição surge como uma alternativa à nossa sociedade, não tanto lucrativa, mas mais solidária, porque "ao investirmos na solidariedade estamos a enriquecer a sociedade".

Fazer a História de uma Instituição é dar-lhe o valor que ela merece, é dar-lhe uma identificação, é dar-lhe vida e prolongá-la no futuro. Mas esta História não se esgota, é um edifício em construção, feito por Homens dotados de ideias e de objectivos concretos. 
Em relação ao futuro, já existem projectos em marcha que passam pelo incremento do turismo na região, respeitando um plano integrado, que pode ser um factor importante de desenvolvimento e de motivação para as populações locais. Ao mesmo tempo, poderá constituir uma fonte de cultura para quem nela desejar beber conhecimento. Tudo isto só será possível se houver uma participação e uma colaboração da comunidade local.

Fica a esperança de que o presente trabalho contribua especialmente para um conhecimento e enriquecimento mais profundo desta Instituição, que tenta minimizar os problemas dos jovens e idosos.

Apesar dos aspectos abordados ao longo do trabalho, subsiste a ideia do muito que fica por dizer. Como se trata do primeiro trabalho realizado, nestes moldes, sobre esta Fundação, fica um contributo pessoal para que estudos posteriores possam vir a ser realizados.

Em suma, esperamos que esta obra continue a crescer e a dar frutos, dando continuidade ao muito que já realizou, ao longo de mais de três décadas.

\section{NOTAS}

* O presente trabalho, sobre a Fundação Joaquim dos Santos situada em Torredeita, surge no âmbito do seminário de História Económica e Social e Cultura de Empresa, que se insere no plano curricular do $4^{\circ}$ ano da Licenciatura em Gestão e Desenvolvimento Social.

Não podemos terminar este trabalho sem manifestar gratidão ao Professor Doutor Amado Mendes pela orientação prestada e pelos conhecimentos ministrados no referido "Seminário". Queremos deixar também uma palavra de agradecimento ao Sr. Inspector Arcides Baptista Simões e à $\mathrm{Dr}^{\mathrm{a}}$ Paula Martins, Directora do Lar pela disponibilidade e pelo auxílio prestado. Finalmente uma palavra de apreço ao Sr. Presidente da Junta de Freguesia, Sr. Alberto Ascensão, e à Vice-Presidente da Cooperativa "O Enleio", Sr ${ }^{a} \mathrm{D}$. Rosa Monteiro, pela colaboração prestada. Para finalizar e não menos importante fica o agradecimento ao Sr. Alexandre Simões pela colaboração e dedicação dispensada.

1 "Torredeita", Viseu Municipalis, Boletim Informativo Municipal, Ano II, nos 2 e 3, 1989, p.95.

2 Vide Mapa em anexo.

3 “Torredeita", Viseu Municipalis, Boletim Informativo Municipal, Ano II, $\mathrm{n}^{\text {os }} 2$ e 3, 1989 , p.95.

${ }^{4}$ BEXIGA, Fernando Luís Monteiro - Torredeita a Terra e o Homem, Viseu, Ecomuseu do Rancho Folclórico de Torredeita, 1989, p.12.

${ }^{5}$ Idem, Ibidem.

${ }^{6}$ COELHO, José - Memórias de Viseu (arredores), Vol. I: Viseu, Beira Histórica, Arqueológica e Artística, 1941, p.434.

7 "Fundação Joaquim dos Santos", Voz de Torredeita e Boa Aldeia, Ano XIV n² 138, Junho de 1997, p.2. 
${ }^{8}$ DRUCKER, Peter F. - As Organizações Sem Fins Lucrativos, Lisboa, Difusão Cultural, 1990, p. 19 e 58.

${ }^{9}$ Inquérito Anual às Instituições Particulares de Solidariedade Social, Instituto Nacional de Estatística (INE), 1993.

${ }^{10}$ Idem, Ibidem.

${ }^{11}$ Diário do Governo n. ${ }^{\circ} 288$, III série, de 10 de Dezembro de 1965 , cuja revisão foi publicada no Diário da República n. $^{\circ} 67$, de 1983.

${ }^{12}$ Livro das Fundações de Solidariedade Social sob o n. ${ }^{\circ} 62 / 83$ a fls. 199 verso e 200 , em 26/08/83.

${ }^{13}$ Diário da República - II série, n. ${ }^{\circ} 48$, de 27 de Fevereiro de 1988.

${ }^{14}$ MELLO, Pedro Homem de - Folclore, Lisboa, Edições Ática, 1971, p.189.

15 BEXIGA, Fernando Luís Monteiro - Torredeita a Terra e o Homem, Viseu, Ecomuseu do Rancho Folclórico de Torredeita, 1989, p.16.

${ }^{16}$ VASCONCELOS, José Leite de - Etnografia Portuguesa,vol. I, Lisboa, Imprensa Nacional, Casa da Moeda, 1980, p. 6 e 7.

${ }^{17}$ Citado por Fernando Bexiga, na obra Torredeita a Terra e o Homem, p. 22.

18 Instituto do Emprego e Formação Profissional (IEFP) - Delegação Regional do Centro - Artesanato da Região Centro, Coimbra, 1992, p.313.

${ }^{19}$ Idem, Ibidem.

${ }^{20}$ No âmbito e alcance do disposto no Dec. - Lei no $26 / 89$ de 21 de Janeiro, revogado por Dec. - Lei $\mathrm{n}^{\mathrm{0}}$ 70/93 de 10 de Março com o celebrado e reciprocamente aceite contrato de programa de 25 de Setembro de 1989 homologado em 13/11/89, entre o Estado (representado pelo GETAP - Gabinete de Educação tecnológica Artística e Profissional cujas prerrogativas se integram no DES - Departamento do Ensino Secundário) e a Fundação Joaquim dos Santos (promotora da Escola Profissional de Torredeita).

${ }^{21}$ Contribuinte n. $503286320 \mathrm{e}$, como tal, goza das prerrogativas das Pessoas Colectivas de Utilidade Pública.

22 "Escola Profissional de Torredeita - Trabalhar em Prol de uma Comunidade", Revista Portugal Local, Edições Regionais, Ano I, nº 16, p. 13. 


\section{ANEXO}

\section{Mapa das Freguesias do Concelho de Viseu}

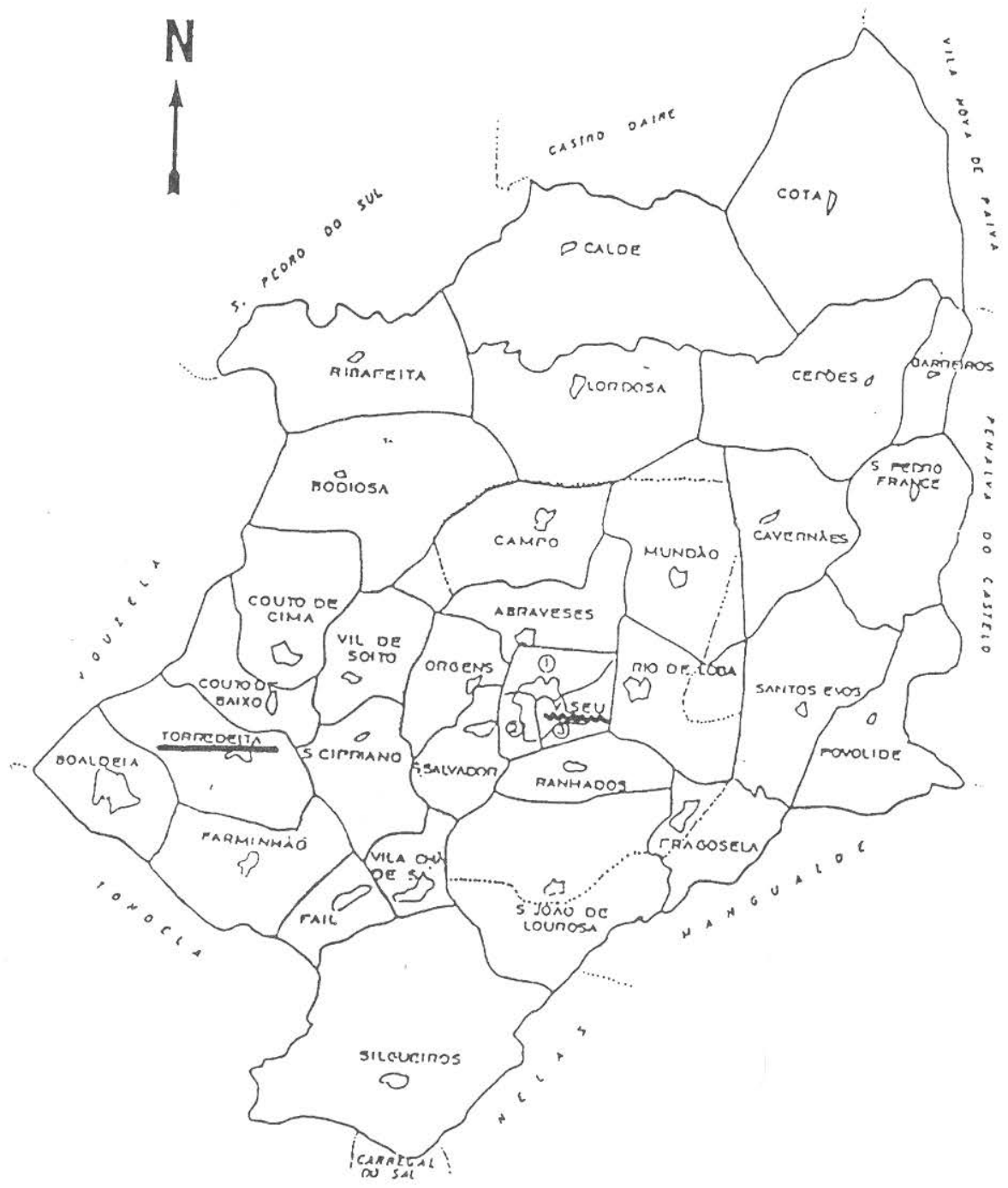

Fonte: Junta de Freguesia de Torredeita 
2. Fotografia aérea do Complexo da Fundação Joaquim dos Santos (Torredeita)

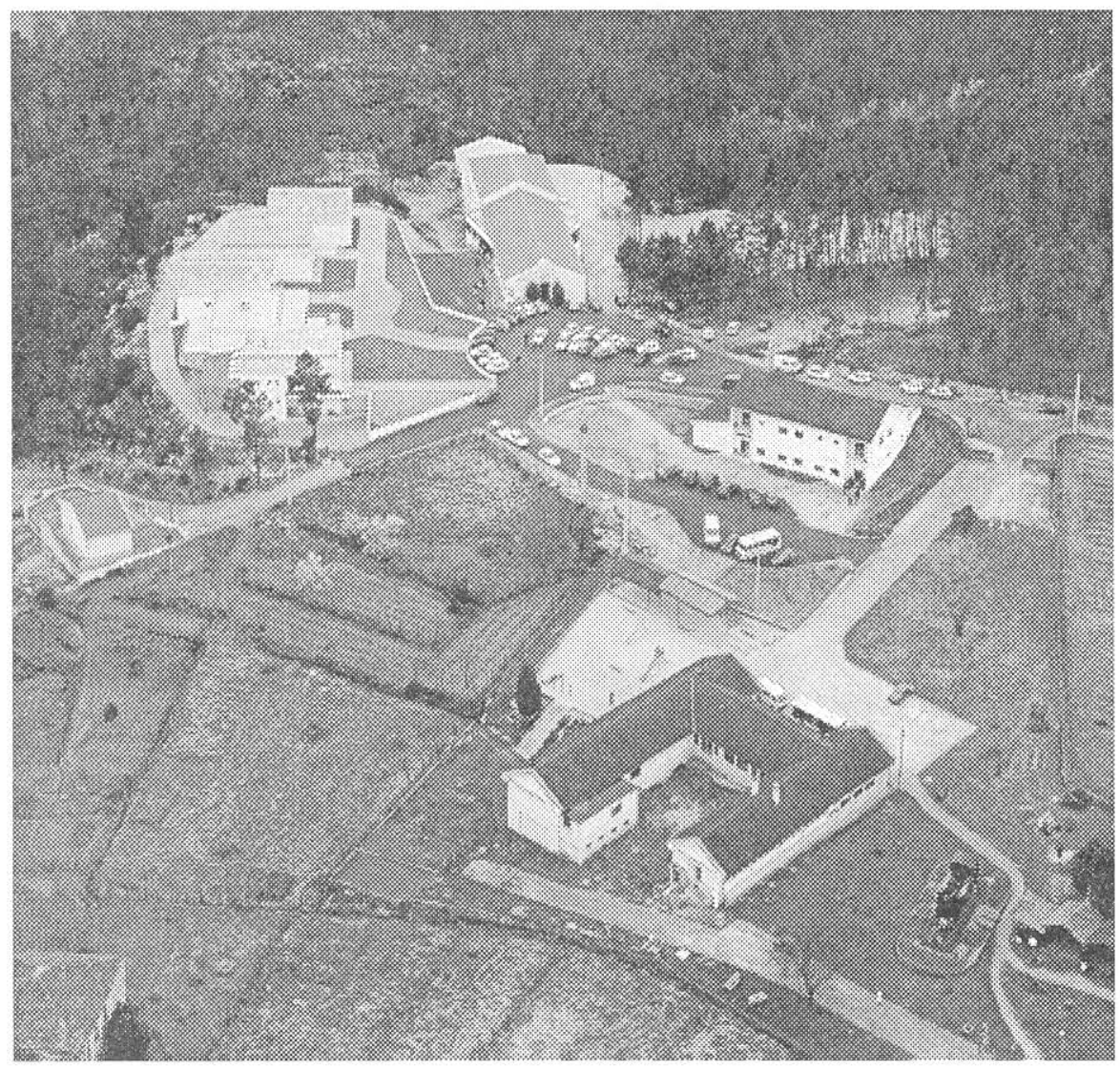


3. Fotografia do Rancho Folclórico de Torredeita (Junho de 1994)

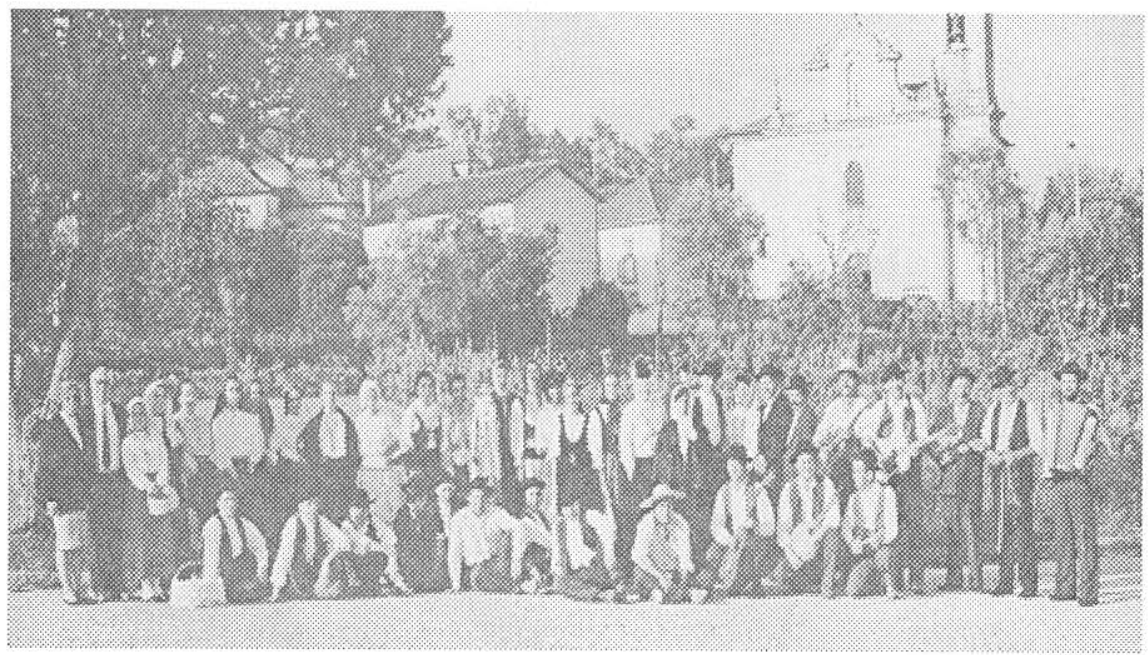

4. Locomotiva a Vapor E124 - "Peça" pertencente ao Ecomuseu

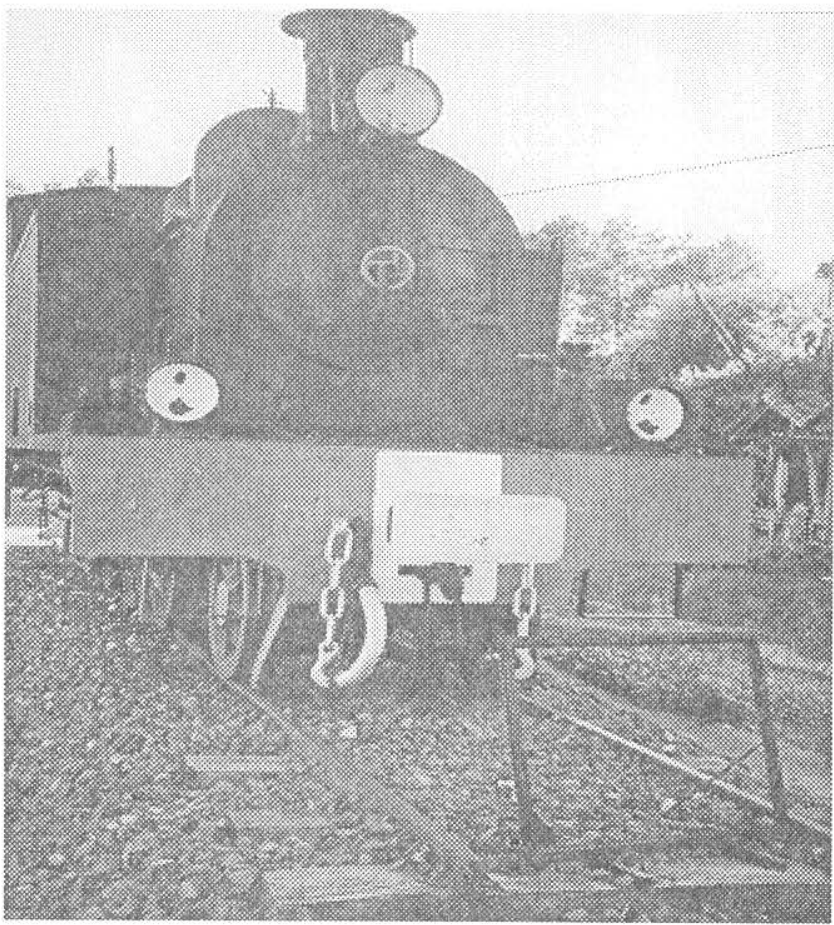




\section{Parte Exterior do Lagar de Azeite da Cepeda}

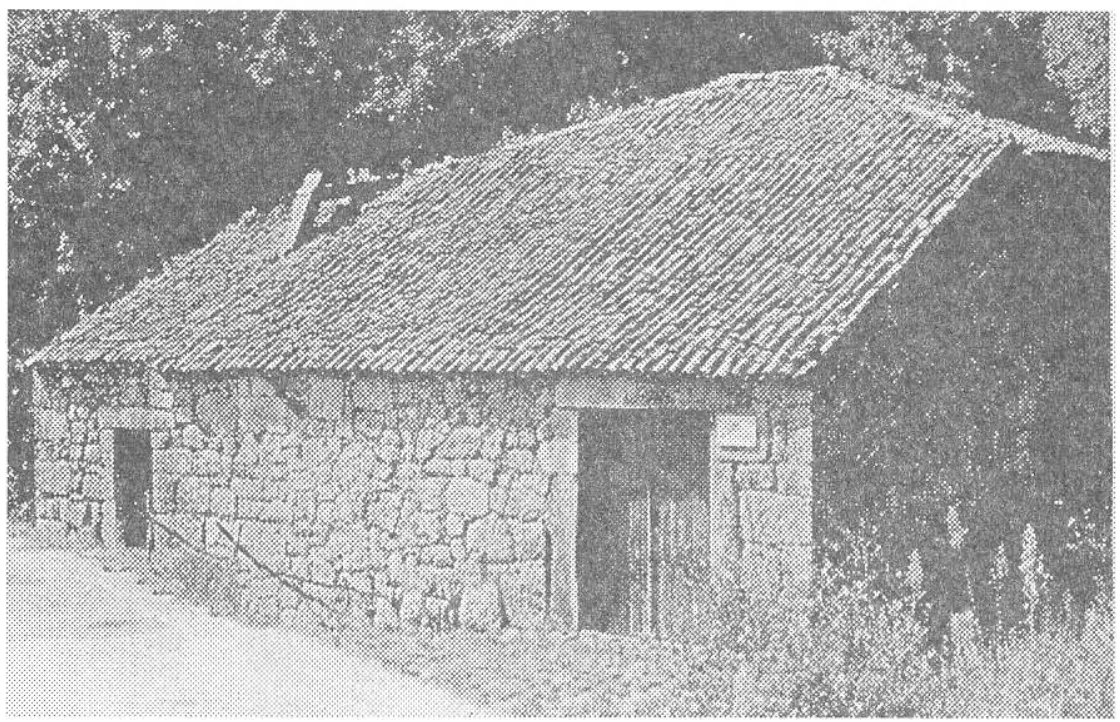

\section{Cooperativa de Artesanato "O Enleio"}

Rendas de Bilros em fase de execução e algumas peças já elaboradas como sejam: golas, toalhas, jogos de sala, ...

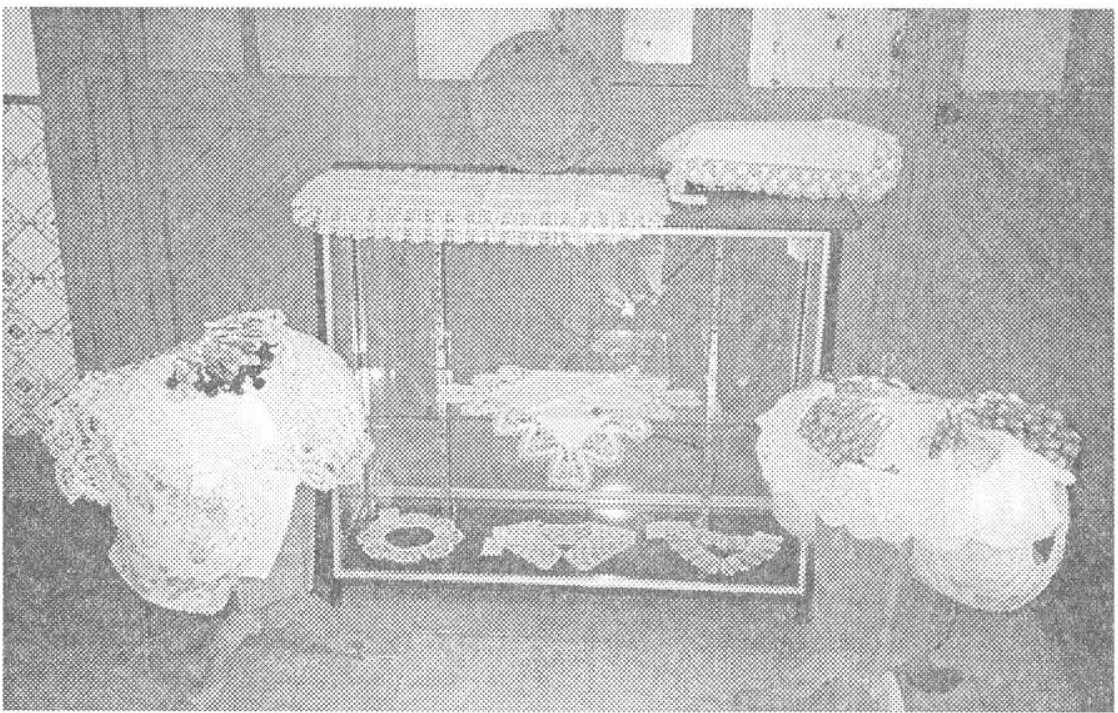




\section{FONTES E OBRAS DE CONSULTA}

\section{FONTES MANUSCRITAS}

Carta dirigida ao Presidente do Concelho de Gerência da Companhia Caminhos de Ferro Portugueses (10-07-1994).

Cópia da Acta da Assembleia da Junta de Freguesia (25-04-1996).

Estatutos da Fundação Joaquim dos Santos.

Outros documentos fomecidos pela Fundação Joaquim dos Santos, como sejam:

Prospectos; "Curriculum Vitae" do Rancho Folclórico de Torredeita

Outros documentos avulsos

Proposta do projecto do Comboio Histórico e Turístico apresentada em Assembleia Municipal (30-09-1994)

Regulamento Interno da Fundação Joaquim dos Santos

\section{FONTES IMPRESSAS}

Diário da República, I Série A, no 58 (10-03-1993)

Diário da República, II Série, no 48 (27-02-1988)

Diário da República, III Série, no 67 (22-03-1983)

Inquérito Anual às Instituições de Solidariedade Social (IPSS), Instituto Nacional de Estatística (INE) - 1993

Notícias de Viseu, ano XX, no 1042, 5 de Outubro de 1994

Voz de Torredeita e Boa Aldeia, ano XIV, no 138, Junho de 1997

Registo da Fundação na Direç̧ão Geral da Segurança Social (20-08-1996)

Registo de Pessoa Colectiva (02-05-1990)

Viseu Municipalis, Boletim Informativo Municipal, Ano II, nos 2 e 3, 1989

\section{FONTES ORAIS}

Sr. Alberto Ascensão

Sr. Inspector Arcides Baptista Simões

D. Paula Martins

D. Rosa Monteiro

\section{FONTES ICONOGRÁFICAS E CARTOGRÁFICAS}


Fotografias de Peças do Ecomuseu

Fotografias do Lagar de Azeite da Cepeda (exterior)

Fotografias da Cooperativa de Artesanato “O Enleio" (Rendas de Bilros)

Mapa das freguesias do concelho de Viseu

\section{OBRAS DE CONSULTA}

BEXIGA, Fernando Luís Monteiro (1989), Torredeita a Terra e o Homem, Viseu, Ecomuseu do Rancho Folclórico de Torredeita.

COELHO, José (1941), Memórias de Viseu (Arredores), vol. I, Viseu, Beira Histórica, Arqueológica e Artística.

DRUCKER, Peter F. (1990), As Organizações Sem Fins Lucrativos, Lisboa, Difusão Cultural.

FERNANDES, A de Almeida (1998), Toponimia de Torredeita, Viseu.

IEFP (Instituto do Emprego e Formação Profissional) - Delegação Regional do Centro (1992), Artesanato da Região Centro, Coimbra.

MELLO, Pedro Homem de (1971), Folclore, Lisboa, Edições Ática.

Revista Portugal Local, (s/d), Edições Regionais, Ano I, no 16.

VASCONCELOS, José Leite de (1980), Etnografia Portuguesa, Vol. I, Lisboa, Imprensa Nacional - Casa da Moeda. 